\title{
IS ATOPY RELATED TO NEUROTICISM, STRESS, AND SUBJECTIVE QUALITY OF LIFE?*
}

\author{
Biserka RADOŠEVIĆ-VIDAČEK, Adrijana KOŠĆEC, Marija BAKOTIĆ, Jelena MACAN, \\ and Jasminka BOBIĆ
}

Institute for Medical Research and Occupational Health, Zagreb, Croatia

Received in July 2008

Accepted in October 2008

\begin{abstract}
Different psychosocial characteristics have been associated with allergic disorders. The aim of this study was to examine whether atopic constitution and reports of allergic symptoms were related to personality trait of neuroticism, exposure to stressful life events and estimates of quality of life. Atopy was determined by skin prick test and reports of nasal and pulmonary allergy-related symptoms. Actively working individuals of both genders took part in the study ( $\mathrm{n}=145$, age range: 20 to 66 years). The participants were divided in three groups. The first group was composed of those with negative skin prick test and without symptoms $(\mathrm{n}=57)$, the second of those with positive skin prick test but without symptoms $(\mathrm{n}=28)$, and the third of those with positive skin prick test and symptoms $(\mathrm{n}=60)$. The groups did not differ significantly in neuroticism, exposure to stressful life events, or quality of life. Women reported more pronounced neuroticism and anxiety, higher exposure to stressful life events, and were less satisfied with their environment than men. In our sample of active workers we found no association of neuroticism, exposure to stressful life events, and quality of life with atopy and allergic symptoms.
\end{abstract}

KEY WORDS: allergic symptoms, biopsychosocial model, gender differences, psychosocial factors, skin prick test

The interest in the relationship between psychosocial factors and allergic diseases may historically be linked to a period when underlying inflammatory basis of allergic diseases was not revealed, and allergic diseases were considered to be of psychosomatic origin. Nowadays, the studies of their relationship can be viewed from the standpoint of the biopsychosocial model of disease (1-5). The model postulates that one needs to take into consideration the interaction between biological, psychological, and social factors to be able to understand different disease outcomes, i.e. vulnerability to disease, disease onset, expression of symptoms, disease progression, exacerbation, recovery, survival, and associated quality of life. Within the model (5), psychological

* The results were partly presented at the scientific meeting "Allergotoxicological Studies of Environment in Croatia" in Zagreb on 14 May 2008. and social factors influence disease processes through domains of psychosocial processes, health behaviours, stress, and the domain of health psychological interventions (5). Psychosocial processes include factors such as personality traits, various moods and social relationships, and resources which are important for the interpretation of and responses to life events and stressors. Health behaviours include factors such as alcohol and drug use, smoking, sleep, nutrition, exercise, and adherence to medical regimens. The effects of all these factors are mediated through neuroendocrine and immune mechanisms, and in an interaction with the biological characteristics of a person they may have different disease outcomes (5).

Epidemiological and clinical studies have examined the relationships between several psychosocial factors and allergic diseases, predominantly asthma (6, 
7). Some of the studies examined the relationships between allergic diseases and various personality traits, such as neuroticism $(8,9)$, anxiety $(10-12)$, extraversion/introversion (9), shyness $(13,14)$, and depression (11). Others were more oriented towards relationships with psychological processes which were supposed to be less stable over time in comparison to traits. They include studies of the relationships between allergic diseases and exposure to various stressors $(9,15-19)$, stress vulnerability $(10)$, social support and conflicts $(17,18)$, stress reactions, and mental health $(9,20-23)$. Health behaviours and coping with allergic diseases were also studied (24). In the domain of health psychological interventions the effects of writing about stressful events were studied (25). Some studies investigated the associations between allergic diseases and quality of life $(9,26)$. A meta-analysis of prospective studies of the relationship between psychosocial factors and allergic disorders (7) revealed a positive association between psychosocial factors and future allergic disorders as well as between allergic disorders, and future poor mental health. In addition, it indicated that in healthy populations, psychosocial factors had the aetiological effect on allergic disorders and in a population with already developed allergic disorders they had a prognostic effect for the course of the disorder.

The majority of studies performed till now have examined the association between psychosocial factors and allergic diseases, and did not attempt to distinguish between asymptomatic atopic constitution and allergy symptoms. Atopy is defined as a personal and/or familial tendency, usually in childhood or adolescence, to become sensitised and produce $\operatorname{IgE}$ antibodies in response to ordinary exposures to allergens. Atopy should be documented by objective markers, i.e. IgE antibodies in serum or by a positive skin prick test. A person of the atopic constitution may develop typical allergic symptoms of asthma, rhinoconjuctivitis, or eczema (27).

Timonen et al. $(28,29)$ studied the relationship between objectively documented atopy and depression. Atopy was documented by the skin prick test, while depression was diagnosed by a doctor and its severity measured with a symptom checklist. The authors found that atopic women had a greater risk of being diagnosed as depressive than did non-atopic women, and the risk was higher in those having clinically manifest atopic disorders (28). This association was not observed in men. When the subjects were also categorised according to the severity of depression symptoms (29), the authors observed a higher proportion of diagnosed depressions in women with a positive prick test and suffering from allergic symptoms than in women with a negative skin prick test and without allergy symptoms irrespective of depression severity. In men, however, this association was found only in subjects having the most pronounced symptoms of depression (29). Klokk et al. (30) studied the relationships between total and allergen-specific $\mathrm{IgE}$ and symptoms of anxiety and depression in women. Unlike Timonen et al. $(28,29)$, they did not find any association between depression/anxiety and IgE levels.

In this study we were able to examine the relationship between objectively documented atopy and three psychosocial factors which were previously found to be related to allergic diseases in studies that did not objectively determine atopy. We examined the relationships with factors from different psychosocial domains of the biopsychosocial model of disease. Two of them might affect vulnerability to disease and manifestation of disease symptoms. One was the trait of neuroticism $(8,9)$ from the domain of psychosocial processes. The other was exposure to life events (18) from the domain of stress. In addition, we investigated the relationship with subjective quality of life (9) from the domain of disease outcomes. The aim of this study was to see whether there were any differences in neuroticism, exposure to stressful life events, and subjective quality of life between subjects who differed with respect to presence of atopy and allergic symptoms. The differences were evaluated taking into account the gender, as some studies have indicated that the relationship between psychosocial factors and allergic disease differ between men and women $(8,28,29)$.

\section{SUBJECTS AND METHODS}

This study was a part of a larger project on immunotoxic effects of indoor bioaerosols and lifestyle factors conducted at the Institute for Medical Research and Occupational Health, Zagreb, Croatia. The project included subjects who were employed and actively working at the time of the study. They participated on a voluntary basis, and signed an informed consent before they entered the study. The project was designed in accordance with the Declaration of Helsinki, and approved by the Institute's Ethics Committee. 


\section{Subjects}

The initial sample comprised 220 workers who received the information about the study at their workplace and applied voluntarily for participation. Seventy five participants were excluded, as they reported respiratory symptoms which were not related to atopy. Therefore, in this study we analysed the data of 145 participants (of whom 107 were women). Their age ranged from 20 years to 66 years (mean $=43.45$ years, $\mathrm{SD}=9.85$ years). According to education level, six subjects had elementary school level, 66 secondary school level, and 73 university level. One hundred and thirty-nine were "white collar" workers, and six "blue collar" workers.

The subjects were asked to pay a visit to the Institute twice in one week. On the first day they went through an extensive medical interview and skin prick testing, whereas psychosocial factors were examined on the second day. The procedure and results of other examinations are reported elsewhere (e.g. 31, 32).

\section{Skin prick test}

Skin prick testing (SPT) was performed using a standard method (33) with a panel of common inhalatory allergens, including grass pollen mixture, birch, hazel, weed (Ambrosia elatior, Artemisia vulgaris) pollens, mites Dermatophagoides pteronyssinus, Dermatophagoides farinae, and Lepidoglyphus destructor, cat, dog, and moulds Cladosporium herbarum and Alternaria alternata (Allergopharma, Germany). SPT included testing with positive control solution (10 mg mL-1 of histamine hydrochloride) and negative control solution (buffer solution). Skin reaction (wheal) was evaluated after $15 \mathrm{~min}$. The mean skin reaction (mean wheal diameter) was calculated according to the formula $(\mathrm{D}+\mathrm{d}) / 2$, where $\mathrm{D}$ represented the largest longitudinal diameter and $\mathrm{d}$ its midpoint orthogonal diameter in $\mathrm{mm}$. For statistical evaluation of the SPT results, the difference between mean skin reaction to each allergen and negative control solution was used as a parameter of SPT reactivity. The results of SPT were considered positive when the mean wheal diameter was larger than the negative control for $3 \mathrm{~mm}$ or more to at least one tested allergen.

\section{Allergic symptoms}

A questionnaire including general data and medical history was completed by a physician for each subject. Data about a history of nasal and pulmonary symptoms were also collected. Nasal symptoms included sneezing, watery rhinorrhea, and nasal obstruction (not related to common cold), which are the symptoms compatible with the recent definition of allergic rhinitis proposed by the Allergic Rhinitis and its Impact on Asthma (ARIA) Workshop guidelines (34). Pulmonary symptoms included episodic dry cough, wheezing, and dyspnoea, which is compatible with the Global Initiative for Asthma (GINA) guidelines for diagnosing asthma (35). Those who reported one or more nasal symptoms and/or two or more pulmonary symptoms were considered to have allergic symptoms.

The subjects were assigned to one of three groups, according to their SPT results for inhalatory allergens, and to their allergic symptoms (Table 1). The groups did not differ by gender $\left(\chi^{2}=3.305, \mathrm{df}=2, \mathrm{p}=0.192\right)$ or age $\left(\mathrm{F}_{(2 / 142)}=0.499, \mathrm{p}=0.608\right)$.

\section{Psychosocial factors}

The quality of life was assessed using the World Health Organization Quality of Life Questionnaire (WHOQOL-BREF, 36). The WHOQOL-BREF consists of 26 questions, of which 24 are divided in four domains of quality of life: Physical Health (7 items), Psychological Health (6 items), Social Relations (3 items), and Environment (8 items). The two remaining questions refer to Overall Quality of Life and General Health. The subjects estimated the quality of their lives over the previous two weeks, and each answer was rated on a Likert-type scale from 1 to 5 . The mean score on items within each domain was multiplied by four, thus converting scores to a range between 4 and 20 . The higher score indicated better QOL. High internal consistency and test-retest stability had already been established for the Croatian version of the WHOQOLBREF in an earlier study (37).

The data on stress levels were assessed by means of the Social Readjustment Rating Scale (SRRS), (38). The SRRS comprises a list of 43 life events (e.g. death of a spouse, child birth, change in residence, change in job, getting married, completing education), which are listed by the rank order of their stressfulness. The participants were asked to mark all the events that had taken place in their life over the previous 12 months. The total score on the SRRS represents the sum of all marked events, scored from 119 to 22 , according to the scale values by Miller and Rahe (39). The theoretical range of the scores is 0 to 2117, with higher score indicating higher stressfulness of life. 
Table 1 Study subjects by gender and group

\begin{tabular}{|c|c|c|c|}
\hline \multirow[b]{2}{*}{ Groups } & \multicolumn{2}{|c|}{ Gender } & \multirow[b]{2}{*}{ Total } \\
\hline & Men & Women & \\
\hline SPT-, AS- & 12 & 45 & 57 \\
\hline SPT,+ AS- & 11 & 17 & 28 \\
\hline $\mathrm{SPT}+, \mathrm{AS}+$ & 15 & 45 & 60 \\
\hline Total & 38 & 107 & 145 \\
\hline
\end{tabular}

SPT+=skin prick test positive

$S P T-=$ skin prick test negative

$A S+=$ with allergy symptoms

$A S-=$ without allergy symptoms

Neuroticism was assessed using the Cornell Index Form N3 $(40,41)$. Cornell Index is a selfadministered multi-scale measure of personality traits and psychosomatic disturbances. It comprises 100 questions grouped in 12 scales: Hypersensitivity (12 items), Phobia (7 items), Anxiety (11 items), Depressiveness ( 7 items), Cardiovascular conversions (5 items), Inhibitory conversions (9 items), Gastric conversions (11 items), Hypochondria (13 items), Obsessive compulsive tendencies (6 items), Impulsive tendencies (3 items), Aggression (9 items), and Psychopathic tendencies ( 7 items). Ten additional questions constitute a "lie scale" with items of high desirability and low endorsement, and a "frequency scale" with items of high desirability and high endorsement. Total score is used as a measure of Neuroticism, with higher score indicating higher level of neuroticism, i.e. lower level of emotional stability. Since the "lie scale" and "frequency scale" are not scored, the theoretical range of total scores is 0 to 100

\section{Statistical analyses}

Two-way analyses of variance were performed with the following dependent variables: Neuroticism (total score in the Cornell Index), Anxiety (subscale of the Cornell Index), four domains of the quality of life: Physical Health, Psychological Health, Social Relations, and Environment (results in the WHOQOLBREF by domains), and Stress (total score in the SRRS). The between-subject factors in all analyses were Group (negative SPT without symptoms, positive SPT without symptoms, positive SPT with symptoms) and Gender (men, women).

For the Depression subscale of the Cornell Index, nonparametric Kruskal-Wallis test was performed for the grouping factor Group (negative SPT without symptoms, positive SPT without symptoms, positive SPT with symptoms) and Mann-Whitney U test for the grouping factor Gender (male, female).

In all analyses, $\mathrm{p}$ values of less than 0.05 were considered significant.

\section{RESULTS}

The results of the ANOVAs are given it the Table 2 , and the mean values by group and gender are given in the Table 3 . Table 2 shows that the only significant effect was the main effect of Gender. The differences between men and women were found for Neuroticism as a total score in the Cornell Index, for the Anxiety subscale of the Cornell Index, for the domain of the Environment in the WHOQOL-BREF, and for stress levels in the SRRS. Women showed greater neuroticism, anxiety and stress levels, and were also less satisfied with their environment than men.

The scores on the Depression subscale of the Cornell Index grouped around zero (median $=0$, mode $=0$ ). The Mann-Whitney $U$ test showed that the depression score did not differ between men and women $(\mathrm{Z}=-1.856, \mathrm{p}=0.063)$, and the Kruskal-Wallis test showed no differences between the three groups $\left(\chi^{2}=3.324, \mathrm{df}=2, \mathrm{p}=0.190\right)$.

\section{DISCUSSION}

The relationship between allergic disorders and various psychosocial factors has been studied extensively (6-26). However, there are few studies that examined the associations between objectively measured atopy and psychosocial factors (28-30, 42). Our study has attempted to give further insight 
Table 2 The ANOVA results - F ratios and p values by the variability sources for each dependent variable

\begin{tabular}{|c|c|c|c|c|c|c|c|c|}
\hline & & \multicolumn{7}{|c|}{ Dependent variable } \\
\hline & & \multicolumn{2}{|c|}{ Cornell Index } & \multicolumn{4}{|c|}{ WHOQOL-BREF } & \multirow{2}{*}{$\begin{array}{l}\text { SRRS } \\
\text { Stress }\end{array}$} \\
\hline $\begin{array}{l}\text { Variability } \\
\text { source }\end{array}$ & & Neuroticism & Anxiety $^{1}$ & $\begin{array}{c}\text { I. } \\
\text { Physical } \\
\text { Health } \\
\end{array}$ & $\begin{array}{c}\text { II. } \\
\text { Psychological } \\
\text { Health } \\
\end{array}$ & $\begin{array}{c}\text { III. } \\
\text { Social } \\
\text { Relations }\end{array}$ & $\begin{array}{c}\text { IV. } \\
\text { Environment }\end{array}$ & \\
\hline \multirow[t]{2}{*}{ Group } & $F$ & 0.805 & 0.129 & 1.165 & 0.311 & 1.300 & 0.490 & 0.000 \\
\hline & $\mathrm{p}$ & 0.449 & 0.876 & 0.315 & 0.733 & 0.276 & 0.614 & 1.00 \\
\hline \multirow[t]{2}{*}{ Gender } & $\mathrm{F}$ & 6.466 & 4.940 & 1.535 & 3.164 & 2.203 & 5.456 & 4.749 \\
\hline & $\mathrm{p}$ & 0.012 & 0.028 & 0.217 & 0.077 & 0.140 & 0.021 & 0.031 \\
\hline Group x & $\mathrm{F}$ & 0.013 & 0.230 & 1.480 & 2.138 & 0.928 & 1.568 & 0.296 \\
\hline Gender & $\mathrm{p}$ & 0.987 & 0.795 & 0.231 & 0.122 & 0.398 & 0.212 & 0.744 \\
\hline
\end{tabular}

Note: ${ }^{1}$ Subscale of the Cornell Index; Significant effects presented in bold

in these associations by examining the relationship between atopy determined on the basis of the skin prick test, and neuroticism, exposure to stressful life events, and subjective quality of life, measured with questionnaires.

Sensitisation to common allergens and development of typical symptoms of an allergic disease usually occurs in childhood and adolescence. However, a recent study has shown a significant increase in the prevalence of atopy markers (IgE antibodies, positive skin prick test) in Croatian adult population in the period between 1985 and 1999, particularly in men (43). The reasons for the first occurrence of atopic diseases in adulthood are still unknown. The possible role of gene-environment interactions and of sex hormones in the development and outcome of the atopy are to be explored in future studies $(44,45)$. This study has examined the association of psychosocial factors with atopy and concurrent allergic symptoms in adulthood.

In a study of self-reported asthma diagnosis in adult population, higher levels of neuroticism were related to higher prevalence of asthma, but no such relationship was observed with the incidence of asthma (9). In a cross-sectional study of self-reported allergy in adult population (8), higher levels of neuroticism were associated with increased likelihood of diagnosed allergy. This association was specific for men. The results of these studies indicate that the relationship between neuroticism might be gender specific, and that neuroticism was not relevant for the aetiology of allergic disorders. In our study, atopic subjects did not show higher levels of neuroticism in comparison to non-atopic, regardless of whether they reported

Table 3 Estimated marginal means and standard errors (in parentheses) for dependent variables by group and gender

\begin{tabular}{|c|c|c|c|c|c|c|c|}
\hline & \multicolumn{7}{|c|}{ Dependent variable } \\
\hline & \multicolumn{2}{|c|}{ Cornell Index } & \multicolumn{4}{|c|}{ WHOQOL-BREF } & \multirow{2}{*}{$\begin{array}{l}\text { SRRS } \\
\text { Stress }\end{array}$} \\
\hline & Neuroticism & Anxiety $^{1}$ & $\begin{array}{c}\text { I. } \\
\text { Physical } \\
\text { Health } \\
\end{array}$ & $\begin{array}{c}\text { II. } \\
\text { Psychological } \\
\text { Health } \\
\end{array}$ & $\begin{array}{c}\text { III. } \\
\text { Social } \\
\text { Relations } \\
\end{array}$ & $\begin{array}{c}\text { IV. } \\
\text { Environment }\end{array}$ & \\
\hline \multicolumn{8}{|l|}{ Group } \\
\hline SPT-, AS- & $13.89(1.65)$ & $3.44(0.38)$ & $16.22(0.37)$ & $15.51(0.37)$ & $15.83(0.48)$ & $14.46(0.36)$ & $187.59(20.71)$ \\
\hline SPT+, AS- & $11.71(1.98)$ & $3.57(0.46)$ & $15.63(0.41)$ & $15.12(0.42)$ & $15.52(0.54)$ & $14.05(0.40)$ & $187.37(24.04)$ \\
\hline SPT,+ AS + & $14.86(1.51)$ & $3.71(0.35)$ & $15.49(0.32)$ & $15.18(0.33)$ & $14.83(0.42)$ & $14.54(0.32)$ & $187.12(18.91)$ \\
\hline \multicolumn{8}{|l|}{ Gender } \\
\hline Men & $10.96(1.69)$ & $3.05(0.38)$ & $16.04(0.36)$ & $15.66(0.37)$ & $14.98(0.47)$ & $14.83(0.35)$ & $160.53(20.76)$ \\
\hline Women & $16.01(1.06)$ & $4.10(0.24)$ & $15.54(0.23)$ & $14.89(0.23)$ & $15.81(0.30)$ & $13.86(0.22)$ & $214.19(13.25)$ \\
\hline
\end{tabular}

$S P T+=$ skin prick test positive

$S P T-=$ skin prick test negative

$A S+=$ with allergy symptoms

$A S$ - =without allergy symptoms

Note: ${ }^{\prime}$ Subscale of the Cornell Index; ${ }^{2}$ Skin Prick Test; Significant differences presented in bold 
allergic symptoms or not. If the subjects with high neuroticism had perceived allergy symptoms more readily than those with low neuroticism (8), we would have found higher neuroticism in atopic subjects who reported allergic symptoms. However, these are not our findings. We did not examine the level of neuroticism with respect to the diagnosis of the allergic disease, but with respect to the reports of allergic symptoms. Therefore, we do not know how many of our atopic subjects who reported allergic symptoms perceived their symptoms serious enough to visit a doctor, and whether they had been diagnosed with allergic disease. Consequently, we can not speculate on the possible impact of diagnosed allergic diseases on the level of neuroticism, which was implied by earlier studies $(8,9)$.

The use of Cornell Index in our study made it also possible to analyse anxiety and depression, factors which have often been found to be related to allergic diseases (10-12). Klokk et al. (30) did not find any relationship between atopy, i.e. level of $\mathrm{IgE}$, and symptoms of anxiety/depression in women. Based on those results, the authors did not doubt that there in fact was an association between anxiety and depression and allergic diseases, but they questioned the relevance of $\operatorname{IgE}$ as a common factor in that association. Similarly, in our study we did not find a significant association of anxiety and depression with atopy (i.e. positive skin prick test). The findings of an association between atopy and development of life-time depression in some studies $(28,29,42)$ do not contradict our finding, as none of our subjects had diagnosed depression. Furthermore, we only measured self-reported symptoms of depression, which turned out to be virtually non-existent in our sample.

The relationship between stress and allergic disease has received substantial scientific attention. Some studies evaluating the association between exposure to stressors and allergic diseases indicated significant associations while others did not. Thus, in a healthy adult population, stressful life events were found to be associated with the rate of asthma hospital admissions (18), but daily stress did not predict the onset of asthma (9). In adults who had already developed asthma (46), different types of stress were not found to be associated with asthma morbidity. Severely traumatic events, which happened before the age of 16 , predicted asthma at adult age (47). In our study, stressful life events experienced over the previous 12 months were not related to atopy and reports of allergic symptoms. This negative finding is consistent with the results of a recent meta-analysis (7), which showed that mere exposure to stressors, either stressful life events or daily stressors, did not increase the risk of allergic disorders. Only when exposure to stressors evoked negative stress reactions or when social support was poor, they had an adverse impact on allergic disorders (7). Those findings pointed out the importance of individual differences in reacting to the same stressors, and the importance of supportive social relations in the development of allergic diseases.

Allergic diseases may have a major impact on the quality of life in various domains (26). In our study, we did not find significant differences in the subjective estimate of life quality in the domains of Physical Health, Psychological Health, Social Relations, or Environment between non-atopic subjects, atopics without allergic symptoms, and atopics with allergic symptoms. These findings may indicate that asymptomatic atopy does not affect quality of life in general, and that neither do relatively mild allergic symptoms which were observed in our study.

The only significant differences in psychosocial characteristics were observed between men and women. The significantly higher neuroticism and anxiety in women is consistent with earlier studies $(48,49)$. In our study, women also showed higher stress levels due to exposure to life events. This may reflect both a greater number of perceived stressful events and the perception of more stressful life events in women. Gender differences in exposure to stressful life events have not been consistent in previous studies (50). Some confirmed them, and in others women reported more events only in certain categories (e.g. interpersonal relations), while some studies did not find any gender differences in life event exposure. We also observed that women gave lower estimates of their quality of life in the domain of Environment than men. This may reflect the level of satisfaction with environmental aspects that are in some way specific for our sample, since there are no similar findings in a pool of data obtained in 23 countries (51).

Our sample may be somewhat specific, and that may have influenced the obtained results. Namely, the sample gathers adult working population whose participation in the study was not determined by the presence of any allergic disease. Furthermore, the fact that our subjects were working at the time of the study, speaks for itself about their general state of health. This probably narrowed the range of variations in reported symptoms and negative psychological states. 
Our study has some limitations. Firstly, due to the cross-sectional design we could not examine the temporal relations between psychosocial factors, atopy, and concomitant allergic symptoms. Only a longitudinal study would enable an analysis of possible causal bidirectional relations between psychosocial factors and atopy. Secondly, we did not give a reference time period for questions about allergic symptoms, and therefore registered any history of allergic symptoms. This should not confound a possible relation between reported allergic symptoms and stable psychological characteristic such as Neuroticism. However, it may have confounded possible relations with exposure to stress and perceived quality of life in different domains, which were registered for a defined reference period. Thirdly, the Cornell Index scores were generally low, indicating good mental health of our subjects. Taking into account that our sample included subjects from active working population, we expected that a vast majority of scores for Neuroticism, Anxiety, and Depression would fall into a relatively narrow range of normal results. Yet, the narrow range of scores may have contributed to non-significant relations between scores of scales from the Cornell Index and atopy.

The results of this study based on cross-sectional design did not indicate any association between atopy and psychosocial characteristics. There were also no indications that the presence of allergic symptoms in atopic subjects made any difference in their psychosocial characteristics in comparison with characteristics of atopics without symptoms or characteristics of non-atopics.

\section{Acknoweldgements}

This study was supported by a grant from the Institute for Medical Research and Occupational Health (IMI$655)$.

\section{REFERENCES}

1. Engel GL. The need for a new medical model: A challenge for biomedicine. Science 1977;196:129-36.

2. Cohen S, Herbert TB. Health psychology: Psychological factors and physical disease from the perspective of human psychoneuroimmunology. Ann Rev Psychol 1996;47:11342.

3. Baum A, Posluszny DM. Health psychology: Mapping biobehavioral contributions to health and illness. Ann Rev Psychol 1999;50:137-63.

4. Kiecolt-Glaser JK, McGuire L, Robles TF, Glaser R. Emotions, morbidity, and mortality: New perspectives from psychoneuroimmunology. Ann Rev Psychol 2002;53:83107.
5. Lutgendorf SK, Costanzo ES. Psychoneuroimmunology and health psychology: an integrative model. Brain Behav Immun 2003;17:225-32.

6. Lehrer P, Feldman J, Giardino N, Song HS, Schmaling K. Psychological aspects of asthma. J Consult Clin Psychol 2002;70:691-711.

7. Chida Y, Hamer M, Steptoe A. A Bidirectional relationship between psychosocial factors and atopic disorders: A systematic review and meta-analysis. Psychosom Med 2008;70:102-16.

8. Goodwin RD, Castro M, Kovacs M. Major depression and allergy: does neuroticism explain the relationship? Psychosom Med 2006;68:94-8.

9. Houvinen E, Kaprio J, Koskenvuo M. Asthma in relation to personality traits, life satisfaction, and stress: A prospective study among 11000 adults. Allergy 2001;56:971-7.

10. Buske-Kirschbaum A, Ebrecht M, Kern S, Gierens A, Hellhammer DH. Personality characteristics in chronic and non-chronic allergic conditions. Brain Behav Immun 2008:22:762-8.

11. Centanni S, Di Marco F, Castagna F, Boveri B, Casanova F, Piazzini A. Psychological issues in the treatment of asthmatic patients. Respir Med 2000;94:742-9.

12. Stauder A, Kovács M. Anxiety symptoms in allergic patients: identification and risk factors. Psychosom Med 2003;65:81623.

13. Bell IR, Jasnoski ML, Kagan J, King DS. Is allergic rhinitis more frequent in young adults with extreme shyness? A preliminary survey. Psychosom Med 1990;52:517-25.

14. Kagan J, Snidman N, Julia-Sellers M, Johnson MO. Temperament and allergic symptoms. Psychosom Med 1991;53:332-40.

15. Sandberg S, Paton JY, Ahola S, McCann DC, McGuinness D, Hillary CR, Oja H. The role of acute and chronic stress in asthma attacks in children. Lancet 2000;356:982-7.

16. Kilpeläinen M, Koskenvuo M, Helenius H, Terho EO, Stressful life events promote the manifestation of asthma and atopic diseases. Clin Exp Allergy 2002;32:256-63.

17. Giardino ND, Schmaling KB, Afari N. Relationship satisfaction moderates the association between catastrophic cognitions and asthma symptoms. J Asthma 2002;39:74956.

18. Wainwright NW, Surtees PG, Wareham NJ, Harrison BD. Psychosocial factors and incident asthma hospital admissions in the EPIC-Norfolk cohort study. Allergy 2007;62:554-60.

19. Turyk ME, Hernandez E, Wright RJ, Freels S, Slezak J, Contraras A, Piorkowski J, Persky VW. Stressful life events and asthma in adolescents. Pediatr Allergy Immunol 2008; 19:255-63.

20. Kovalenko PA, Hoven CW, Wu P, Wicks J, Mandell DJ, Tiet Q. Association between allergy and anxiety disorders in youth. Aust NZ J Psychiatry 2001;35:815-21.

21. Kovács M, Stauder A, Szedmák S. Severity of allergic complaints: the importance of depressed mood. J Psychosom Res 2003;54:549-57.

22. Friedman AH, Morris TL. Allergies and Anxiety in Children and Adolescents: A Review of the Literature. J Clin Psychol Med Settings 2006;13:323-36.

23. Hashizume $\mathrm{H}$, Takigawa M. Anxiety in allergy and atopic dermatitis. Curr Opin Allergy Clin Immunol 2006;6:335- 
24. Barton C, Clarke D, Sulaiman N, Abramson M. Coping as a mediator of psychosocial impediments to optimal management and control of asthma. Respir Med 2003;97:747-61.

25. Smyth JM, Stone AA, Hurewitz A, Kaell A. Effects of writing about stressful experiences on symptom reduction in patients with asthma or rheumatoid arthritis: A randomized trial. JAMA 1999;281:1304-9.

26. Gerth van Wijk R. Allergy: a global problem. Quality of life. Allergy 2002;57:1097-110.

27. Johansson SGO, Bieber T, Dahl R, Friedmann P, Lanier B, Lockey RF, Motala C, Martell J, Platts-Mills TAE, Ring J, Thien F, Van Cauwenberge P, Williams HC. Revised nomenclature for allergy for global use: Report of the Nomenclature Review Committee of the World Allergy Organization, October 2003. J Allergy Clin Immunol 2004;113:832-6.

28. Timonen M, Jokelainen J, Silvennoinen-Kassinen S, Herva A, Zitting P, Xu B, Peltola O, Räsänen P. Association between skin test diagnosed atopy and professionally diagnosed depression: a Northern Finland 1966 Birth Cohort study. Biol Psychiatry 2002;52:349-55.

29. Timonen M, Jokelainen J, Hakko H, Silvennoinen-Kassinen S, Meyer-Rochow VB, Herva A, Räsänen P. Atopy and depression: results from the Northern Finland 1966 Birth Cohort Study. Mol Psychiatry 2003;8:738-44.

30. Klokk M, Götestam KG, Mykletun A. There are no association between IgE levels and symptoms of anxiety and depression in the adult female general population. The Hordaland Health Study (HUSK). Nord J Psychiatry 2007;61:410-7.

31. Gomzi M, Bobic J, Radosevic-Vidacek B, Macan J, Varnai VM, Milkovic-Kraus S, Kanceljak-Macan B. Sick building syndrome: Psychological, somatic and environmental determinants. Arch Environ Health 2007;62:1-9.

32. Pizent A, Macan J, Jurasovic J, Varnai VM, Milkovic-Kraus S, Kanceljak-Macan B. Association of toxic and essential metals with atopy markers and ventilatory lung function in women and men. Sci Total Environ 2008;390:369-76.

33. Dreborg S, Frew A. Position paper: Allergen standardization and skin tests. The European Academy of Allergology and Clinical Immunology Subcommittee on Skin Test. Allergy 1993;48(14 Suppl S):49-82.

34. Bousquet J, Van Cauwenberge P, Khaltaev N. The ARIA Workshop Group. Allergic rhinitis and its impact on asthma - ARIA Workshop Report. J Allergy Clin Immunol 2001;108:S147-S333.

35. NHLBI/WHO Workshop Report. Global strategy for asthma management and prevention. Bethesda (MD): National Institutes of Health; 1995.
36. WHOQOL Group. Development of the World Health Organization WHOQOL-BREF Quality of Life Assessment. Psychol Med 1998;28:551-8.

37. Radosevic-Vidacek B, Macan J, Koscec A. Stress and allergy. Arh Hig Rada Toksikol 2004;55:205-11.

38. Holmes TH, Rahe RH. The social readjustment rating scale. J Psychosom Res 1967;11:213-8.

39. Miller MA, Rahe RH. Life changes scaling for the 1999s. J Psychosom Res 1997;43:279-92.

40. Weider A, Brodman K, Mittelmann B, Wechsler D, Wolff HG. The Cornell Index. Psychosom Med 1946;8:411-3.

41. Weider A, Wolff HG, Brodman K, Mittelmann B, Wechsler D. Priručnik za Cornell Index. Jastrebarsko: Naklada Slap; 1997.

42. Timonen M, Jokelainen J, Herva A, Zitting P, Meyer-Rochow VB, Rasanen P. Presence of atopy in first-degree relatives as a predictor of a female proband's depression: results from the Northern Finland 1966 Birth Cohort. Allergy Clin Immunol 2003;111:1249-54.

43. Macan J, Varnai VM, Maloča I, Kanceljak-macan B. Increasing trend in atopy markers prevalence in a Croatian adult population between 1985 and 1999. Clin Exp Allergy 2007;37:1756-63.

44. Nowak D, Ulrik CS, von Mutius E. Asthma and atopy: Has peak prevalence been reached? Eur Resp J 2004;23:35960.

45. Almqvist C, Worm M, Leynaert B, Working group of $\mathrm{GA}^{2} \mathrm{LEN}$ WP 2.5. Gender. Impact of gender on asthma in childhood and adolescence: A GA ${ }^{2} \mathrm{LEN}$ review. Allergy 2008;63:47-57.

46. Schmaling KB, McKnight PE, Afari N. A prospective study of the relationship of mood and stress to pulmonary function among patients with asthma. J Asthma 2002;39:501-10.

47. Roman S, Belaise C, Martin J, Morris E, Raffi A. Childhood abuse and later medical disorders in women. Psychother Psychosom 2002;71:141-50.

48. Costa PT, Terracciano A, McCrae RR. Gender differences in personality traits across cultures: robust and surprising findings. J Pers Soc Psychol 2001;81:322-31.

49. Feingold A. Gender differences in personality: a metaanalysis. Psychol Bull 1994;116:429-56.

50. Kendler KS, Thornton LM, Prescott CA. Gender differences in the rates of exposure to stressful life events and sensitivity to their depressogenic effects. Am J Psychiatry 2001;158:587-93.

51. Skevington SM, Lotfy M, O'Connell KA. The World Health Organization's WHOQOL-BREF quality of life assessment: Psychometric properties and results of the international field trial. A Report from the WHOQOL Group. Quality Life Res 2004;13:299-310. 
Sažetak

\section{JE LI ATOPIJA POVEZANA S NEUROTIZMOM, STRESOM I SUBJEKTIVNOM KVALITETOM ŽIVOTA?}

Dosadašnja istraživanja upućuju na međusobnu povezanost psihosocijalnih čimbenika i alergijskih poremećaja. Cilj ovog rada bio je ispitati jesu li atopijska konstitucija i alergijski simptomi povezani s neurotizmom kao osobinom ličnosti, izloženošću stresnim životnim događajima i subjektivnim procjenama kvalitete života. Stanje atopije određeno je s pomoću kožnog prick testa te izvještajima o nosnim i plućnim alergijskim simptomima. $\mathrm{U}$ ispitivanju su sudjelovale radno aktivne osobe obaju spolova $(\mathrm{n}=145)$ u dobi od 20 do 66 godina. Sudionici su podijeljeni u tri skupine. Jednu skupinu činili su sudionici s negativnim kožnim prick testom, koji nisu imali alergijske simptome $(\mathrm{n}=57)$. Drugu skupinu činili su sudionici s pozitivnim kožnim prick testom, ali koji nisu imali alergijske simptome $(\mathrm{n}=28)$. Treću skupinu činili su sudionici s pozitivnim kožnim prick testom koji su također imali i alergijske simptome $(\mathrm{n}=60)$. Skupine se nisu značajno razlikovale u neurotizmu, izloženosti stresnim životnim događajima i kvaliteti života. Kod žena je, neovisno o skupini, stupanj neurotizma i anksioznosti bio viši, izvještavale su o većoj izloženosti stresnim događajima te procijenile kvalitetu života u domeni okoliša nižom nego muškarci. Rezultati ovog ispitivanja ne upućuju na povezanost neurotizma, izloženosti stresu i kvalitete života s atopijom i alergijskim simptomima u skupini radno aktivnih osoba.

KLJUČNE RIJEČI: alergijski simptomi, biopsihosocijalni model, kožni prick test, psihosocijalni čimbenici, spolne razlike

CORRESPONDING AUTHOR:

Biserka Radošević-Vidaček, Ph.D.

Institute for Medical Research and Occupational Health

PO Box 291, HR-10001 Zagreb

E-mail: bvidacek@imi.hr 